\section{Breaking the vicious circle of obesity: the metabolic syndrome and low testosterone by administration of testosterone to a young man with morbid obesity}

\author{
Quebrando o círculo vicioso da obesidade: síndrome metabólica \\ e baixos níveis de testosterona pela administração de \\ testosterona a um homem jovem com obesidade mórbida
}

Yuliya Tishova', Svetlana Y. Kalinchenko²

\begin{abstract}
Objective: The metabolic syndrome (MS) is associated with low serum testosterone levels. Conversely, low testosterone levels induce MS. These operational mechanisms reinforce one another and induce a vicious cycle. This is a report on a morbid obesity 42 year-old man with the $\mathrm{MS}$ and serum testosterone of $5.0 \mathrm{nmol} / \mathrm{L}$ ( $\mathrm{N}:$ 12.0-33.0), who was resistant to treatment with diet and exercise. He was treated with testosterone undecanoate for 16 months. Methods: Anthropological and laboratory variables were measured before and during testosterone administration. Also the Aging Male Symptom Scale (AMS), the International Index of Erectile Function (IIEF) and Beck's Depression Inventory were assessed. Results: After 16 months, there was a weight loss of $50 \mathrm{~kg}$ and a decrease in waist circumference of $36.5 \mathrm{~cm}$. Blood pressure normalized and laboratory variables returned to the normal range. The patient did not meet the criteria for the MS anymore. There were improvements on the AMS, the IIEF and Beck's Depression Inventory. Conclusions: Normalizing testosterone in men with morbid obesity in combination with diet and exercise, with the MS and low testosterone levels, may rescue them from the MS, improving their mood and their stamina to follow a diet and to exercise. Arq Bras Endocrinol Metab. 2009;53(8):1046-51
\end{abstract}

Keywords

Obesity; metabolic syndrome; testosterone; erectile function

\section{RESUMO}

Objetivo: A síndrome metabólica (SM) está associada a baixos níveis séricos de testosterona. Inversamente, baixos níveis de testosterona induzem a SM. Esses mecanismos operacionais se reforçam mutuamente e levam a um círculo vicioso. Este é o relato de um homem de 42 anos, obesidade mórbida com SM e testosterona sérica de 5,0 nmol/L ( $\mathrm{N}: 12,0-33,5)$, resistente ao tratamento com dieta e exercícios. Ele foi tratado com undecanoato de testosterona por 16 meses. Métodos: Variáveis antropológicas e laboratoriais foram medidas antes e durante a administração de testosterona. Também foram avaliados a Escala de Envelhecimento Masculino (AMS), o Índice Internacional de Função Erétil (IIEF) e a Escala de Beck para Depressão. Resultados: Após 16 meses, houve uma perda de peso de $50 \mathrm{~kg}$ e diminuição de $36,5 \mathrm{~cm}$ da circunferência abdominal. A pressão arterial foi normalizada e as variáveis laboratoriais também retornaram para os limites de normalidade. 0 paciente não preenchia mais os critérios para SM. Houve melhoras da AMS, do IIEF e da Escala de Beck para Depressão. Conclusões: A normalização da testosterona em homens com obesidade mórbida, combinada à dieta e a exercícios, com SM e baixos níveis de testosterona, pode livrá-los da SM, melhorando o humor e o vigor para seguir uma dieta e exercícios. Arq Bras Endocrinol Metab. 2009;53(8):1046-51

Descritores

Obesidade; síndrome metabólica; testosterona; disfunção erétil
Department of Andrology and Urology, Research Center for Endocrinology, Moscow, Russia ${ }^{2}$ Chair of Clinical Andrology, People's Friendship, University of Russia, Moscow, Russia

Correspondence to: Yuliya Tishova Department of Andrology and Urology, Research Center for Endocrinology

Street D. Ulyanova, 11

Moscow, 117136

Russia

yulya_tishova@mail.rur

Received on Aug/17/2009 Accepted on Oct/30/2009 


\section{INTRODUCTION}

$\mathrm{T}$ the metabolic syndrome (MS) is becoming currently a health issue for a wide range of medical specialties, including endocrinologists, cardiologists, diabetologists, urologists and general practitioners. The International Diabetes Federation (IDF) has formulated criterion (1) for a person to be considered with MS presenting central obesity (defined as waist circumference $\geq 94 \mathrm{~cm}$ for European men and $\geq 80 \mathrm{~cm}$ for European women, with ethnicity specific values for other groups) plus any two of the following four factors:

- raised TG level: $\geq 150 \mathrm{mg} / \mathrm{dL}$ (1.7 mmol/L), or specific treatment for this lipid abnormality;

- reduced HDL cholesterol: < $40 \mathrm{mg} / \mathrm{dL}(1.03$ $\mathrm{mmol} / \mathrm{L}$ ) in males and $<50 \mathrm{mg} / \mathrm{dL}$ (1.29 $\mathrm{mmol} / \mathrm{L})$ in females, or specific treatment for this lipid abnormality;

- raised blood pressure (BP): systolic $\mathrm{BP} \geq 130$ or diastolic $\mathrm{BP} \geq 85 \mathrm{mmHg}$, or treatment of previously diagnosed hypertension;

- raised fasting plasma glucose (FPG) $\geq 100 \mathrm{mg} /$ $\mathrm{dL}(5.6 \mathrm{mmol} / \mathrm{L})$, or previously diagnosed type 2 diabetes mellitus (T2DM).

The prevalence of MS is high in male (from $15 \%$ to $30 \%$ according to the current data) (2). Diagnosing the MS in men is very important in view of dominant role of MS in the development of the diabetes mellitus type and the male preponderance of cardiovascular morbidity and mortality (3). The prevalence of androgen deficiency in men with MS is also quite high $(4,5)$. In recent studies, it has been shown that there is a link between low plasma testosterone and development of the components of MS, such as cardiovascular disease and T2DM $(5,6)$. Also an association between visceral and central obesity and hypogonadism could be established $(7,8)$. Placebocontrolled studies have shown that treatment with androgens of hypogonadal men leads to a reduction of the body mass index (BMI), of visceral obesity, insulin resistance, BP and improvement of the lipid spectrum (9). These data should lead to the development of new approaches of diagnosis and treatment of MS in men and of the role of testosterone in its diagnosis and treatment.

Apart from testosterone deficiency due to congenital or acquired testicular damage (primary hypogonadism) or hypothalamic and hypophyseal failure (secondary hypogonadism) - the "classical" causes of hypogonadism, testosterone deficiency can occur in the process of aging and in severe somatic disease (10). Very often, testosterone deficiency can be diagnosed in men with obesity and MS. While the prevalence of the MS increases with age, also at young age it appears associated with low testosterone levels $(11,12)$. In the latter case, there is probably a vicious circle. Adiposity with its associated hyperinsulinism suppresses sex hormone-binding globulin (SHBG) synthesis and therewith the levels of circulating testosterone (10). It also may affect the strength of LH signaling to the testis (13). Further, insulin (14) and leptin (15) have a suppressive effect on testicular steroidogenesis. Visceral fat cells secrete a large number of cytokines which impair testicular steroidogenesis (16). So, there are reasons to believe that adiposity is a significant factor in lowering circulating levels of testosterone. While it is clear that disease and, in the context of this contribution, in particular, the MS suppress circulating testosterone levels, it has also been documented that low testosterone induces the MS (17).

Our case report demonstrated that it is possible to break into this vicious circle by raising testosterone levels in subjects with the MS, severe obesity and low testosterone who have become resistant to treatment with diet and exercise.

\section{CASE REPORT}

We reported the case of a 42 -year old male patient (Figure 1). He consulted because of weight gain, not responding significantly to the effects of dieting and exercise. He complained of sleep apnea, loss of libido, erectile dysfunction, fatigue, depression and hypertension (up to $165 / 100 \mathrm{mmHg}$ ). The patient was not taking any medication for his condition.

Physical examination revealed normal external genitalia, female type of pubic hair and lipomastia. Anthropometric investigation is largely presented in table 1. Scores on the Aging Male Symptoms Scale (AMS) questionnaire (18) resulted in 50 points, indicating severe androgen deficiency symptoms. Scores on the International Index of Erectile Function (IIEF) (19) were 12 points (moderate Erectile Dysfunction (ED). Beck Depression Inventory $(20)$ resulted in 20 points, which fulfills the criteria of severe depression. Blood tests are also presented in table 1. Transrectal ultrasound revealed normal prostate volume $(20 \mathrm{~mL})$ without any signs of pathology.

Patient was treated with intramuscular testosterone undecanoate $1.000 \mathrm{mg}$ (Nebido, Bayer Schering) following a standard scheme (injections at $0,6,12$ weeks and then at 12 -week intervals). He was advised to follow his diet and continue exercise. 

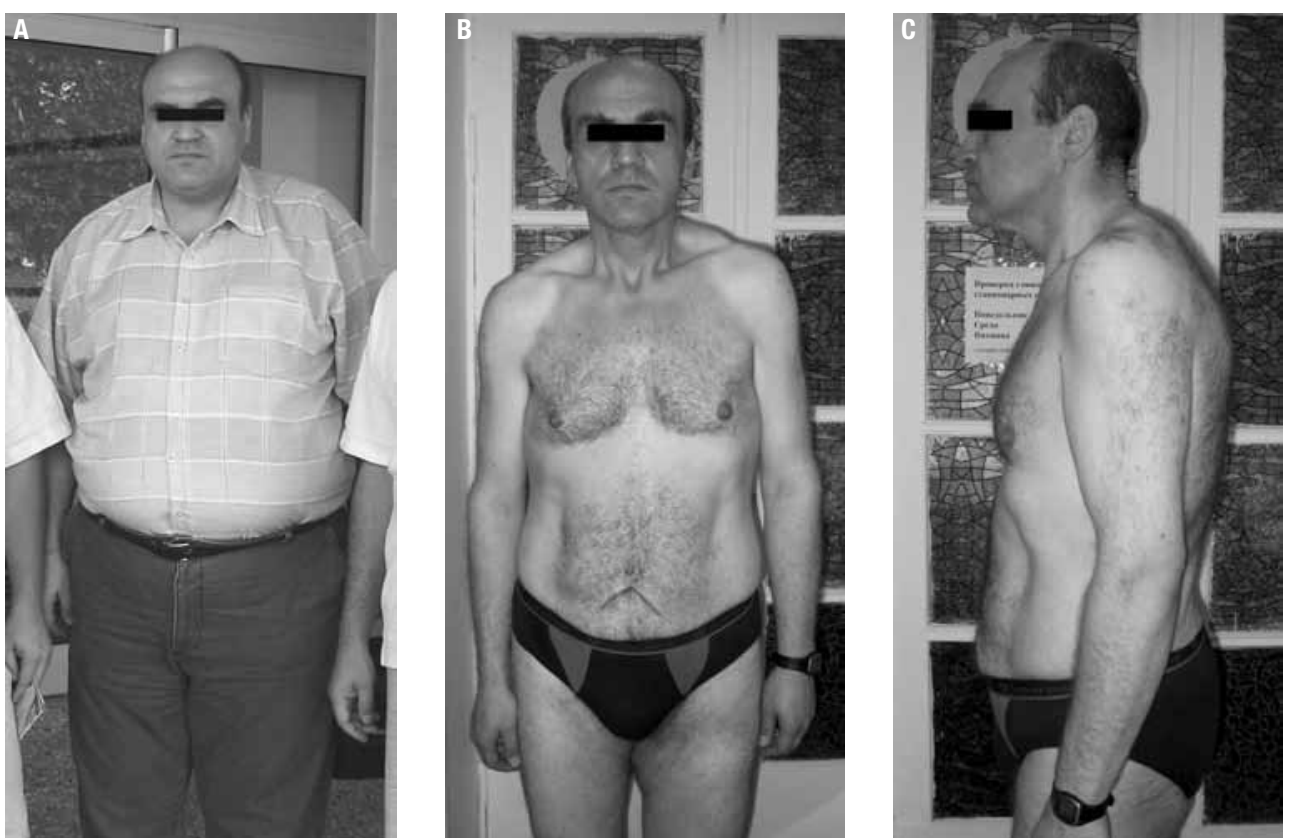

Figure 1. Patient before treatment $(A)$ and after 16 months of treatment $(B$ e $C)$.

\begin{tabular}{lccc}
\hline \multicolumn{3}{l}{ Table 1. Changes in anthropometric/laboratory variables } & \\
\hline Hormones & Normal range & $\begin{array}{c}\text { Before } \\
\text { treatment }\end{array}$ & $\begin{array}{c}\text { After 16 } \\
\text { months of } \\
\text { treatment }\end{array}$ \\
\hline Total testosterone & $13-33.5 \mathrm{nmol} / \mathrm{L}$ & 5.0 & 29.1 \\
SHBG & $12.9-61.7 \mathrm{nmol} / \mathrm{L}$ & 33.9 & 59 \\
Leptin & $<12.0 \mathrm{ng} / \mathrm{mL}$ & 16.8 & 1.3 \\
Insulin & $2.3-26.4 \mathrm{mU} / \mathrm{L}$ & 17.5 & 4.1 \\
Estradiol & $20-240 \mathrm{pmol} / \mathrm{L}$ & 164 & 146 \\
Weight $(\mathrm{kg})$ & 152.0 & 101.8 \\
BMI (kg/m²) & 44.4 & 29.8 \\
Waist circumference (cm) & & 141 & 96 \\
Blood pressure (mmHg) & & $140 / 90$ & $130 / 80$ \\
Cholesterol & $3.3-5.2 \mathrm{mmol} / \mathrm{L}$ & 5.5 & 4.8 \\
HDL & $0.9-2.6 \mathrm{mmol} / \mathrm{L}$ & 1.3 & 1.4 \\
LDL & $0.0-3.7 \mathrm{mmol} / \mathrm{L}$ & 3.4 & 3.1 \\
Triglycerides & $0.1-2.2 \mathrm{mmol} / \mathrm{L}$ & 2.3 & 0.5 \\
Glucose & $3.05-6.38 \mathrm{mmol} / \mathrm{L}$ & 5.0 & 4.2 \\
Total PSA & $0.0-4.0 \mathrm{ng} / \mathrm{mL}$ & 0.4 & 0.5 \\
\hline & & & \\
\hline
\end{tabular}

The patient was followed up every three month for testosterone dose adjustment and checks of prostate specific antigen (PSA) as well as blood count control. Over the 16 months of follow-up, the patient reported improvement of general well-being accompanied with normalization of BP (up to 130-140/80-90 mmHg in self-measurement, sleep, mood, erectile function and libido). Physical examination revealed improvement of all anthropometric parameters (Table $\mathrm{l}$ and Figure 1 ) - hip circumference: $112 \mathrm{~cm}$ (minus $29 \mathrm{~cm}$ ); waist to hip ratio: 0,86 . There was a strong reduction of levels of serum leptin and insulin.

Patient reported that for the whole period of treatment he tried to follow a healthy diet and regular exercise (1-2 times a week swimming and walking).

Re-assessments of AMS scale resulted in 37 points, corresponding with minor clinical signs of androgen deficiency; of IIEF, in 21 points (no erectile dysfunction); and of Becks's Depression Inventory, in 9 points (no depression).

All hormones and lipids returned to the normal ranges and diagnosis of MS was no longer applicable. Patient was recommended to continue treatment with testosterone undecanoate at 12 -week intervals.

Patient consented that his observational data were reported in the literature.

\section{DISCUSSION}

The association between severe obesity and hypogonadism is now well established, also in the younger age group. The low testosterone levels might have induced a vicious circle, since low testosterone levels induce an increase in visceral obesity and severity of cardiovascular risk factors comprised in the MS. Dieting and exercise improve the levels of testosterone and the me- 
tabolic situation (21). In our case, the patients could not be helped only by diet and exercise, maybe also due to a depressive mood, as evidenced by the Beck's Depression Inventory. Administration of testosterone and raising testosterone to eugonadal values brought an amazing and quick recovery over 18 months, with a strong reduction of body weight, and all variables of the MS returned from abnormal to normal. Depressive symptoms improved too.

Mood-elevating effects of testosterone have been reported (22), but the loss of body weight may have had an independent positive effect on mood, though studies indicate that weight loss has a positive effect on psychological factors but improvement of depressive mood states is less clear (23). In population studies, it has been found that erectile function improves when weight declines, so the loss of weight, in this case, may have also been a factor in improvement of scores on the IIEF (24). Effects of weight loss on scores of the AMS have not been reported.

There may have been a role for leptin in this recovery. Leptin is an adipose tissue hormone with socalled "double action": it affects receptors on Leydig cells, lowering testicular testosterone secretion. In addition, leptin suppresses hypophyseal LH secretion. Hypogonadal obese men have elevated leptin levels and testosterone therapy reduces leptin levels in addition to the independent effects of weight loss in lowering leptin levels.

The dramatic weight loss and recovery of the MS was unexpectedly quick and successful. A case report does not allow to make far reaching conclusions as to the mechanism but it could be that, in addition to breaking the self-sustaining vicious circle of MS-obesity hypognadal testosterone levels, the mood-elevating effects of normalizing testosterone may have played a role (22). More studies are needed to distinguish between the effects of weight loss and/or exercise on somatic and mental features associated with the MS and to test whether treatment of testosterone has an additional positive effect. The latter appeared to be the case in a study of men newly diagnosed with T2DM (9).

A case report cannot prove a hypothesis to be correct. In the reported case, diet, exercise and testosterone supplementation were given in combination, thus it is difficult to disentangle each component in the treatment success - though it is of note that the patient had followed a diet and had done exercise earlier, but unsuccessfully.

\section{CONCLUSION}

This case shows that extreme obesity is associated with low levels of testosterone, probably maintaining obesity and the MS. Breaking in into this vicious circle by exogenously raising testosterone levels appeared to have a beneficial effect leading to a strong reduction of body weight and resolution of the signs and symptoms of the MS. Treatment of an obese individual with lifestyle modification and testosterone replacement might be a reasonable alternative for obese patients with moderate to severe signs of hypogonadism. However, this approach has not yet been substantiated in rigorous placebocontrolled studies and, therefore, has not yet found its way into the guidelines of treatment of testosterone deficiency in elderly men as formulated by several professional organizations (25).

Disclosure: no potential conflict of interest relevant to this article was reported.

\section{REFERENCES}

1. Alberti KG, Zimmet $P$, Shaw J. The metabolic syndrome - a new worldwide definition. Lancet. 2005;366(9491):1059-62.

2. Traish AM, Saad F, Guay A. The dark side of testosterone deficiency: II. Type 2 diabetes and insulin resistance. J Androl. 2009;30(1):23-32.

3. Corona G, Forti G, Maggi M. Why can patients with erectile dysfunction be considered lucky? The association with testosterone deficiency and metabolic syndrome. Aging Male. 2008;11(4):193-9.

4. Kalyani RR, Dobs AS. Androgen deficiency, diabetes, and the metabolic syndrome in men. Curr Opin Endocrinol Diabetes Obes. 2007;14(3):226-34.

5. Traish AM, Guay A, Feeley R, Saad F. The dark side of testosterone deficiency: I. Metabolic syndrome and erectile dysfunction. J Androl. 2009;30(1):10-22.

6. Corona G, Mannucci E, Forti G, Maggi M. Hypogonadism, ED, metabolic syndrome and obesity: a pathological link supporting cardiovascular diseases. Int J Androl. 2009.

7. Svartberg J, von Muhlen D, Sundsfjord J, Jorde R. Waist circumference and testosterone levels in community dwelling men. The Tromso study. Eur J Epidemiol. 2004;19(7):657-63.

8. Allan CA, Strauss BJ, McLachlan RI. Body composition, metabolic syndrome and testosterone in ageing men. Int $\mathrm{J}$ Impot Res. 2007;19(5):448-57.

9. Heufelder AE, Saad F, Bunck MC, Gooren L. Fifty-two-week treatment with diet and exercise plus transdermal testosterone reverses the metabolic syndrome and improves glycemic control in men with newly diagnosed type 2 diabetes and subnormal plasma testosterone. J Androl. 2009;30(6):726-33.

10. Kaufman JM, Vermeulen A. The decline of androgen levels in elderly men and its clinical and therapeutic implications. Endocr Rev. 2005;26(6):833-76.

11. Goncharov NP, Katsya GV, Chagina NA, Gooren LJ. Three definitions of metabolic syndrome applied to a sample of young obese men and their relation with plasma testosterone. Aging Male. 2008;11(3):118-22.

12. Haring R, Volzke H, Felix SB, Schipf S, Dorr M, Rosskopf D, et al. Prediction of metabolic syndrome by low serum testosterone le- 
vels in men: results from the study of health in Pomerania. Diabetes.2009;58(9):2027-31.

13. Lima N, Cavaliere H, Knobel M, Halpern A, Medeiros-Neto G. Decreased androgen levels in massively obese men may be associated with impaired function of the gonadostat. Int J Obes Relat Metab Disord. 2000;24(11):1433-7.

14. Pitteloud N, Hardin M, Dwyer AA, Valassi E, Yialamas M, Elahi D, et al. Increasing insulin resistance is associated with a decrease in Leydig cell testosterone secretion in men. J Clin Endocrinol Metab. 2005;90(5):2636-41.

15. Isidori AM, Caprio M, Strollo F, Moretti C, Frajese G, Isidori A, et al. Leptin and androgens in male obesity: evidence for leptin contribution to reduced androgen levels. J Clin Endocrinol Metab. 1999;84(10):3673-80.

16. Eckel RH, Grundy SM, Zimmet PZ. The metabolic syndrome. Lancet. 2005;365(9468):1415-28.

17. Laaksonen DE, Niskanen L, Punnonen K, Nyyssonen K, Tuomainen TP, Valkonen VP, et al. Testosterone and sex hormone-binding globulin predict the metabolic syndrome and diabetes in middleaged men. Diabetes Care. 2004;27(5):1036-41.

18. Heinemann LA, Saad F, Zimmermann T, Novak A, Myon E, Badia $X$, et al. The Aging Males' Symptoms (AMS) scale: update and compilation of international versions. Health Qual Life Outcomes. 2003;1(1):15.
19. Rosen RC, Cappelleri JC, Gendrano N 3rd. The International Index of Erectile Function (IIEF): a state-of-the-science review. Int J Impot Res. 2002;14(4):226-44.

20. Beck AT, Ward CH, Mendelson M, Mock J, Erbaugh J. An inventory for measuring depression. Arch Gen Psychiatry. 1961;4:561-71.

21. Esposito K, Marfella R, Ciotola M, Di Palo C, Giugliano F, Giugliano $G$, et al. Effect of a Mediterranean-style diet on endothelial dysfunction and markers of vascular inflammation in the metabolic syndrome: a randomized trial. JAMA. 2004;292(12):1440-6.

22. Seidman SN, Orr G, Raviv G, Levi R, Roose SP, Kravitz E, et al. Effects of testosterone replacement in middle-aged men with dysthymia: a randomized, placebo-controlled clinical trial. J Clin Psychopharmacol. 2009;29(3):216-21.

23. Blaine BE, Rodman J, Newman JM. Weight loss treatment and psychological well-being: a review and meta-analysis. J Health Psychol. 2007;12(1):66-82.

24. Travison TG, Shabsigh R, Araujo AB, Kupelian V, O'Donnell AB, McKinlay JB. The natural progression and remission of erectile dysfunction: results from the Massachusetts Male Aging Study. J Urol. 2007;177(1):241-6; discussion 6.

25. Wang C, Nieschlag E, Swerdloff R, Behre HM, Hellstrom WJ, Gooren $\mathrm{LJ}$, et al. Investigation, treatment and monitoring of lateonset hypogonadism in males: ISA, ISSAM, EAU, EAA and ASA recommendations. Eur J Endocrinol. 2008;159(5):507-14. 